\title{
Posters, Banners and Billboards Visual Pollution in Nigerian Urban Environment: Challenges to Urban Managers.
}

\author{
E. F. Ogunbodede (Ph.D) and Rufai Sunmola \\ Department of Geography and Planning Sciences Adekunle Ajasin University, P.M.B. 001, Akungba-Akoko, \\ Ondo State, Nigeria.
}

\begin{abstract}
Pollution of environment with chemical substances had received some attention while not much had been done in the area of visual pollution. This paper examined ways by which posters and billboards have impacted negatively on Nigerian's urban environment. The study area covered three (3) senatorial districts of Ondo State - Okitipupa, Igbokoda, Ondo, Akure, Owo and Ikare-Akoko. These towns served as melting points for socio-economic and political activities of their LGAs. Information on sources of posters, target areas for displaying posters, conditions for removal of posters after use, effectiveness of posters in conveying the desired messages, people's perception on its adequacy constitute the information gathered through Questionnaire. The result showed that the highest generator of visual pollution are the politicians which accounted for $45 \%$ of the total waste and followed by churches/mosques (21\%), Entertainment industries (13\%), Education (11\%) and industries/Companies (10\%). In terms of spatial location, the city centre attracted the highest number of posters with $39 \%$, while other junctions attract $22 \%$, bus stop with $16 \%$, school vicinity with $15 \%$ and church/mosques vicinity with $8 \%$. Posters and banners have been found to impede visibility especially around city junctions and in some cases led to accidents. Indiscriminate display of posters reduces the aesthetic value of cities and constitutes irritation to visitors. The paper made some recommendation to city managers.
\end{abstract}

Key words: posters, banners, billboards, visual pollution, negative impact.

\section{Introduction:}

Pollution of land, water and air of chemical substances in both rural and urban environment has received considerable attentions in commissioned studies as well as non-commissioned studies in both developed and developing world. While developed countries are showing considerable success in the abatement of polluted urban centers, not much is done by the developing world. pollution and environmental degradation are posing serious threats to health in both urban and rural areas of Nigeria ${ }^{1}$. This environmental menace is one of the intractable problems in the world's urban centers. For example ${ }^{2-3}$ indicated the general concern globally on the uncontrolled emissions of green house gases especially carbon dioxide. Even at that, a report by the American Lung Association showed that cities across the US have shown success in the fight for cleaner cities. But despite the gains, healthy air remains a goal, not a reality for most US cities. This association found that $58 \%$ of Americans (more than 175 million) live in areas with unhealthy levels of air pollution ${ }^{1}$.

In developed worlds, there are genuine policies towards curtailing pollution. This is not the same in developing countries, where petroleum is produced and gas had been flared since their inception like it happened in Oloibiri oil well in Nigeria since 1956. The report, 'State of the air 2010' showed that a decade of clean-up measures, including reductions in coal-fired powered plants emissions and the transition to cleaner diesel fuels and engines have paid off in curtailing levels of deadly particles and ozone pollution in America in 2006-2008 ${ }^{1}$. According to the America Lung Association, improvements have been seen particularly in Eastern and Midwestern US cities, including Atlanta, Cincinnati, Cleveland, New York city, Pittsburgh, St Louis and Washington DC. Despite this effort, half of the population of the US suffered pollution levels that were too often dangerous to breathe between 2006 and2008. The gladdening news is the increase in public awareness that the environment cannot continue to absorb limitless amounts of waste unabated. This awareness which was initially centered on solid, water and air pollution has been extended to visual pollution. When we use the term pollution we are suggesting that the portion of the built and natural environment we are viewing has been downgraded ${ }^{4}$.

Visual pollution is the term used broadly to cover unattractive and man-made visual elements of a vista, a landscape, or any other thing that a person does not feel comfortable to look at ${ }^{5 \& 10}$. Visual pollution is therefore an aesthetic issue, referring to the impacts of pollution that impact one's ability to enjoy a view. By extension therefore, anything which people do not want in their environment could be termed as pollutants and is better explained from how people perceive posters and banners which are often found in our environment. According to ${ }^{4}$, visual clutter, poor signage, out-of-context architecture, franchise architecture, excess use of poles and wires are just some examples of visual pollution. 
Visual pollution, much of it in the form of advertising, is an issue in all the world's large cities. But what is pollution to some people is a vibrant part of a city's fabric to other ${ }^{6}$. According to him, New York City without Times Square huge digital billboards or Tokyo without the Ginza's commercial panorama is unthinkable. Similarly, Picadilly Circus would be just a London roundabout without its signage. Still, other cities, like Moscow, have reached their limit and have begun to crack down on over-the-top outdoor advertising. In recent years, there is increasing use of posters and banners by politicians, religious bodies as well as corporate bodies to publicise their intentions. These posters and banners which come in form of papers, clothes and billboards (made up of irons and woods) in an attempt to jostle for attention, adorn most urban centres of Nigeria. Some of them are so crowded where they are pasted or mounted to the extent that they impede visibility of people including drivers. Impediments, arising from these uncontrolled displays of posters and billboards have been noted to constitute one of the causes of accidents in some of the cities ${ }^{3}$. The cloth type of posters after use, are left un-removed. In some cases, they are left for a long period that allowed such materials to gather dusts and other micro-organisms that habour respiratory induced diseases. These posters, banners and billboard after some years become eye-sore and when they are removed, could be a potent source and cause of lung diseases like asthma. It could as well trigger-off diseases of health officer/assistants who removed them from our environment. Thus, increasing number of people suffering from these allergies may not be un-connected with this source.

It has also been noted that a large proportion of paper waste that is generated in cities of Nigeria can be traced to posters and banners which were not removed after use in cities. Attempt to reduce paper waste generation through paperless action such as through the use of e-advertisement is therefore defeated. Thus, rather than reduce the volume of paper waste generation in cities, it is always on the increase.

Visual pollution through posters by politicians, religious bodies and other corporate bodies had been on the increase without a corresponding means of evacuating them as soon as their intentions have been made known to the public. Thus, the quantum of waste generation by these activities continues to be on the increase and by extension increase the job of the Waste Management Board. Apart from the visual and aesthetic nuisances which these posters cause to some people, it is the view of some people that as much as possible we should try and imbibe the culture of managing waste if possible rather than to continue to increase it. According to ${ }^{7}$, Ondo State Government has decided to enforce a law to punish people who pasted posters in unlawful places.

The generation and disposal of solid waste is a major public concern of our time and this needs some urgent attention if our environment is to be protected ${ }^{9}$. In view of the highlighted problems, this paper therefore aims at examining ways by which posters and billboards have impacted negatively on Nigerian's urban environment and determine ways by which such challenges could be addressed.

\section{The Study Area}

The study area covers some rapidly developing urban centres in the three (3) senatorial districts of Ondo State. The cities covered include Okitipupa, Igbokoda, Ondo, Akure, Owo and Ikare-Akoko (i.e. two (2) major towns were from each senatorial districts-see Figure 1). These towns in addition to being administrative headquarters of Local Governments in the State also served as industrial, educational and melting points of social and political activities of their Local Governments. Thus, the cities are thickly populated with people from within and outside the States. The thick population of these cities also influence the enormous waste generated through posters, banners and billboards. Of recent, the political activities, Christian crusades as well as companies' promotional activities have made these cities centre points for displaying their posters (cloth and paper), billboards and banners. 
Figure 1: Map of Nigeria showing Ondo State as the Study Area

Selected settlements in the study area
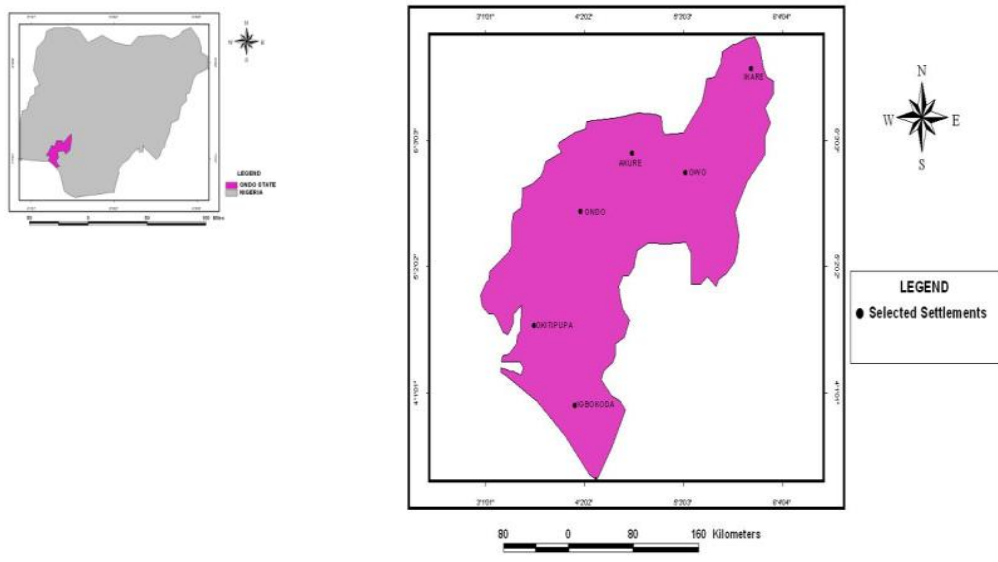

\section{Material and methods}

The materials used for this study include map of the study area and pictures of poster displayed in some parts of the town. Two major sources of data collection were adopted in this study. The primary source which involved the use of structured questionnaire was used to collect information on sources of posters, target areas for displaying posters, removal of the displayed posters after use, motive behind the use of posters, effectiveness of the posters in conveying the desired messages, people's perception on its adequacy or otherwise. The secondary source of information was on the use of relevant articles in journals, dailies and books. The six urban areas were purposively selected for this research work because they serve as central of socio-economic and political activities for their Local Government Areas. Thus, the issues of visual pollution are more prominent and pronounced in the selected six urban areas. In each city, the streets were randomly selected and a total of six hundred (600) respondents were sampled to respond to questions in the questionnaire.

\section{Socio-economic Variables of Respondents:}

\section{Results and Discussions}

The study revealed that overwhelming majority of the respondents was male $(63.6 \%)$ while females made up the remaining 36.4\% (see Table 1). Age brackets between 26 and 54 years constitute $68.8 \%$ of the respondents in the three (3) senatorial districts where this research was carried out. This age brackets (2654 years) constitute the active sector of the population who are involved in politics, church programme activities, entertainment industries and the likes which often make use of posters, banners handbills etc. The marital status shows that $37 \%$ are single, $47.7 \%$ are married and $15.3 \%$ are either separated or divorced. The statistics of the respondent's duration in the study area confirmed that $78.8 \%$ of the respondents have spent more than 11 and above years in their place of abode. This is very significant in this study as it confirms that these respondents understand the terrain of the environment and can easily mount banners and posters with little or no opposition. Table 1 further revealed with interest and curiosity that $93 \%$ of the respondents are literates, they possess not less than secondary education. This educational level of attainment is a pointer that the communities under study are literate and could easily assess both print and audio media of advertisement as a substitute to posters and banners display in cities.

\section{Sources of Posters, Banners and billboards in Nigerian urban Environment}

The survey carried out in the three (3) senatorial districts of Ondo State shows that politicians dominated the major source of posters, banners and billboards in cities thus accounting for about $45 \%$ (see Figure 1). It could be more than that during the peak period of electioneering campaigns. Next to it is religious revivals which pervade almost all the Pentecostal churches that made use of posters and banners to inform different denominations of church crusades as well as programmes. Figure 1 shows that posters and banners emanating from this source accounted for about $18 \%$ of the total banners in Ondo State Urban environment. Others that are involved in posters, banners and leaflets generations include the education sector (14\%), companies (10\%) and entertainment industries with $13 \%$. 
Table 1: Socio-Demographic Characteristics of Respondents

\begin{tabular}{|l|l|l|}
\hline Sex & & \\
\hline Male & 368 & 63.6 \\
\hline Female & 232 & 36.4 \\
\hline Total & 600 & 100 \\
\hline & & \\
\hline Age & & \\
\hline Below 25 years & 120 & 20.4 \\
\hline Bet. 26 and 34 & 200 & 36.0 \\
\hline Bet. 35 and 44 & 106 & 17.2 \\
\hline Bet. 45 and 54 & 98 & 15.6 \\
\hline 55 years and above & 76 & 11.2 \\
\hline Total & 600 & 100 \\
\hline & & \\
\hline Marital Status & & \\
\hline Single & 222 & 37 \\
\hline Married & 286 & 47.7 \\
\hline Separated & 92 & 15.3 \\
\hline Total & 600 & 100 \\
\hline & & \\
\hline $\begin{array}{l}\text { Duration of Stay of respondent in } \\
\text { the study area (years) }\end{array}$ & & \\
\hline 0 - 10 & 127 & 21.2 \\
\hline 11 - 20 & 169 & 28.2 \\
\hline 21 and above & 304 & 50.6 \\
\hline Total & 600 & 100 \\
\hline & & \\
\hline Educational level & 6 & \\
\hline No formal education & 36 & 06 \\
\hline Primary education & 234 & 39 \\
\hline Secondary education & 324 & 54 \\
\hline Tertiary education & 600 & 100 \\
\hline Total & \\
\hline & & \\
\hline & & \\
\hline & & \\
\hline & & \\
\hline & & \\
\hline & & \\
\hline & & \\
\hline & & \\
\hline & & \\
\hline & & \\
\hline & & \\
\hline & & \\
\hline & & \\
\hline
\end{tabular}

The sources of paper and cloth posters in the city centres have been traced to corporate organizations, churches, educational institutions and politicians during the period of election (see Figure 2). In Nigeria, the rate at which posters adorn the nooks and crannies of the city is usually on the increase when election to political positions is on (see Plate 1).

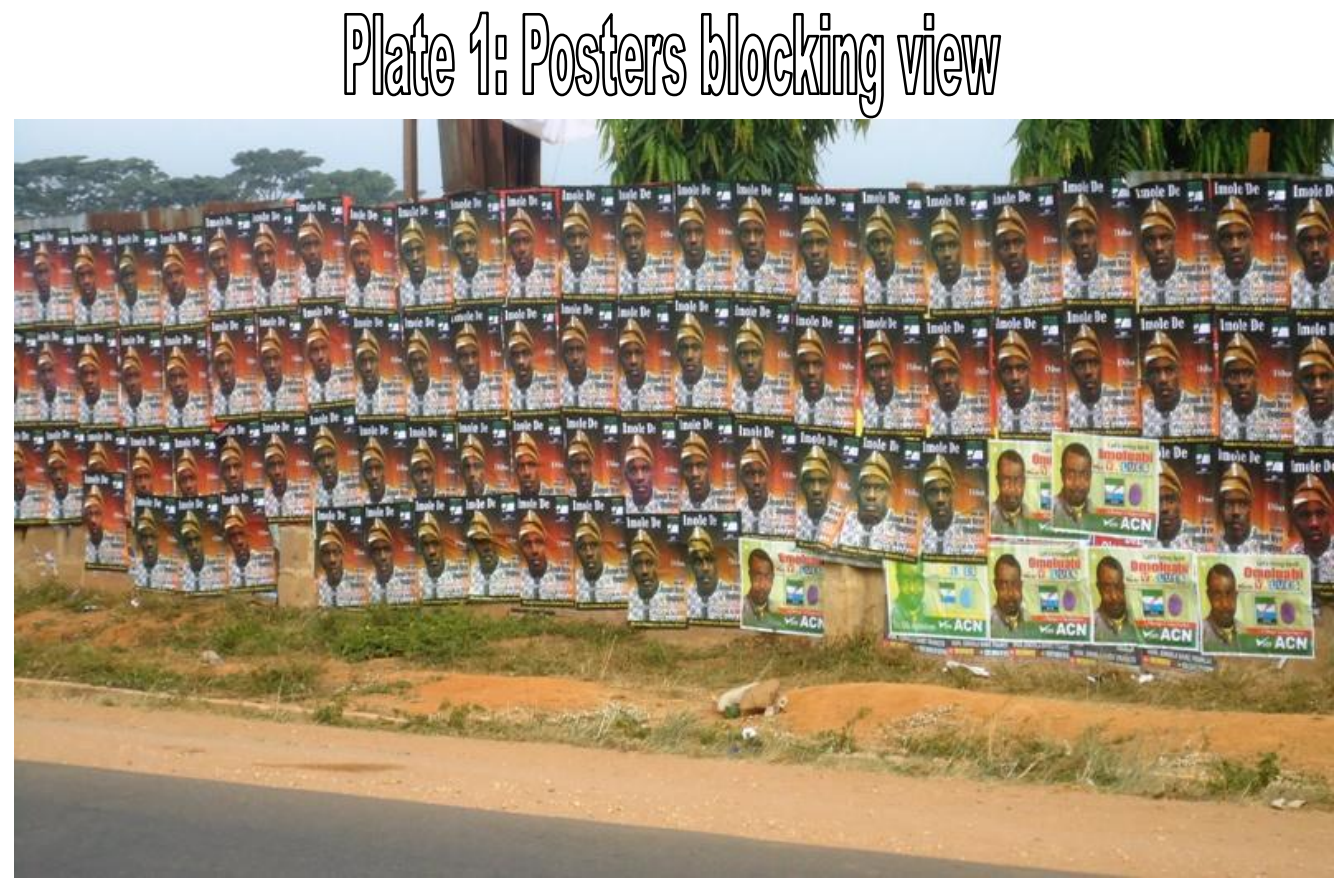

This is because politicians contesting for various positions believed that they can reach out to most electorates through the display of their posters. It is also believed that most electorates would be able to assess 
mandates which are usually summarized in their posters. According to ${ }^{8}$, another reason for the use of posters is because some election could be postponed like it happened during the national assembly election in Nigeria. According to him, the politicians contesting for elective posts had to depend on posters and handbills among other means of communication for their campaigns.

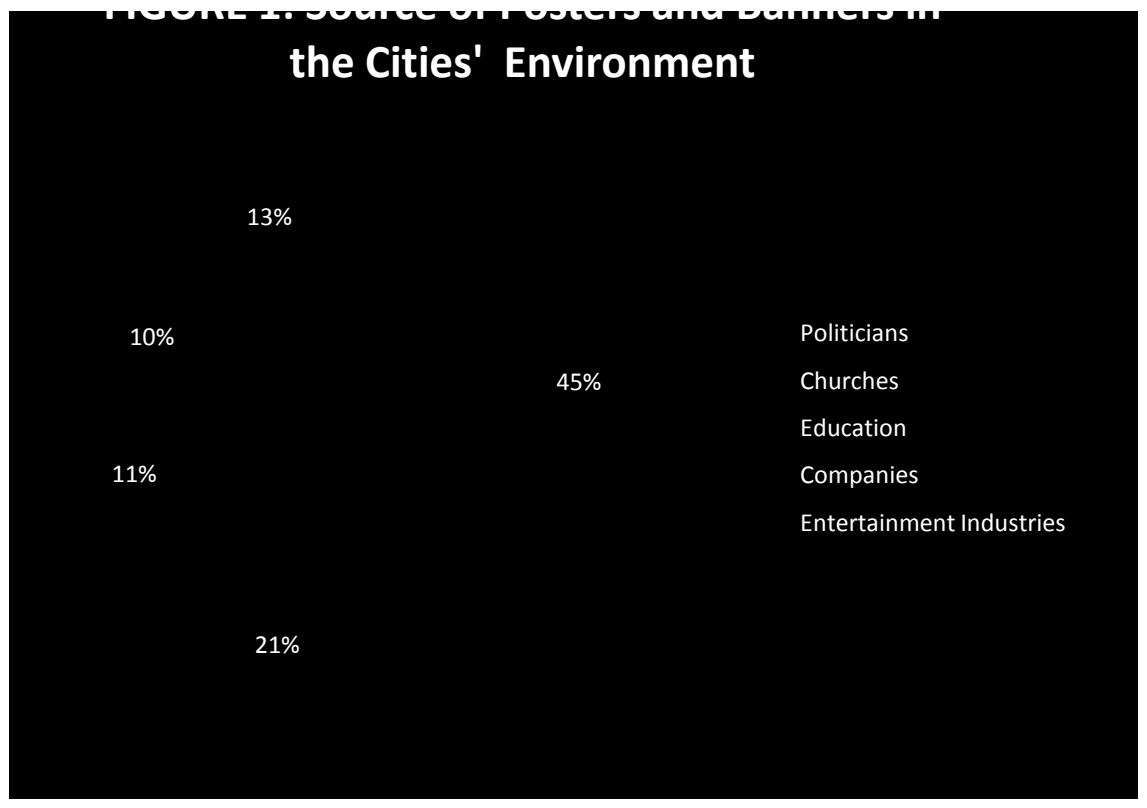

The demand for posters and handbills is on the increase. This has impacted positively on some business outfits such as printers and those who paste them. According to ${ }^{8}$, globally, experts believed that this type of venture is good for those looking for business with relatively low overheads and great earning potentials. Apart from this, the service of distributing handbills and pasting of posters is a serious business that had enjoyed patronage. It was discovered that many businesses need the service of people to distribute their handbills and paste their posters in strategic positions. Therefore, beyond election periods, fast food restaurants, beauty salons, night clubs, marketing outfits, tutorial centres and event planners are therefore potential source of income to the entrepreneur interested in pasting and distributing posters and handbills.

\section{Structures on which Posters and Banners are mounted in Urban Environment}

The structures on which posters and banners are mounted in urban environment are of various dimensions and magnitude depending on the size of such posters and banners and availability of structures on which to mount them. The survey of this research shows that posters are largely mounted but not limited to the following structures - walls, fences, gates, planks, sign boards/posts, poles, bus stops, rocks, abandoned vehicles (see Plate 2), bricks and concrete. It was discovered that religious posters are often concentrated in church environment while that of educational are concentrated in schools/institutions.

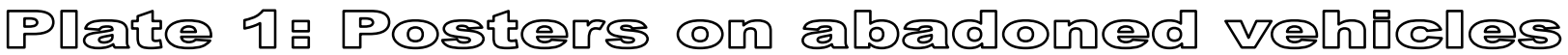

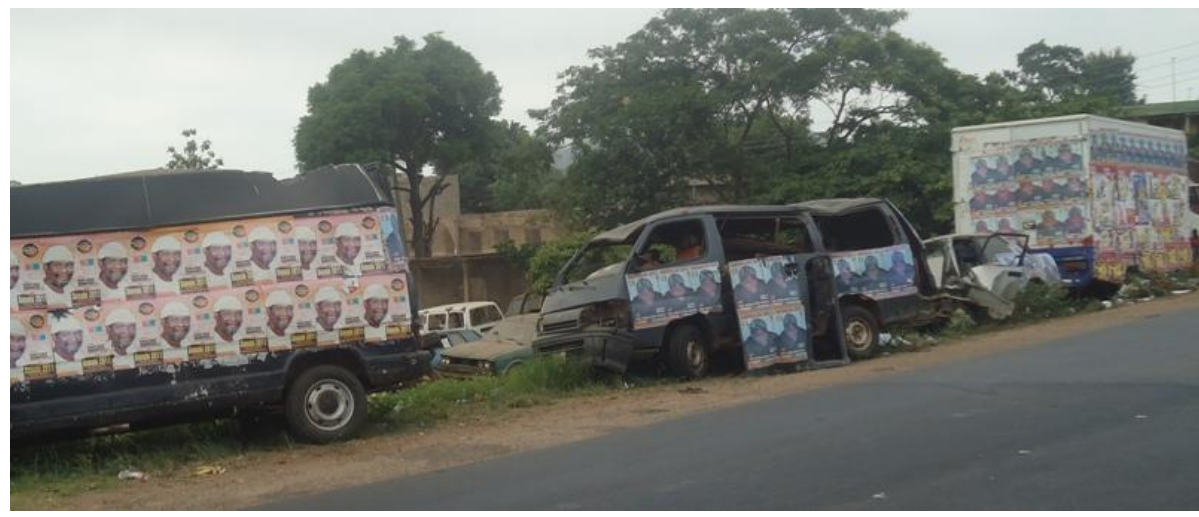


The display of political posters and banners cut across the city centres as well as the remote areas of the city. This also depends on the financial positions of the contestants as well as the political position for which they are making the contest. Thus, for the Governorship position, the posters cut across all the Local Government Areas (LGAs) of the State. For the position of the Senate, Representative, the posters are restricted to few LGAs within which the Senators and Representatives come from. Thus, the number of posters and banners displayed reduces with the importance of the positions of the political offices. For example Table 2 shows the estimated volumes of wastes that are likely to be generated during election period in Ondo State using the list of Local Government aspirants for the following positions, LG councillorship, Members of House Assembly, Members of House of Representative, Member of House of Senate and Governorship position.

Table 2: Estimated waste (posters) generated by political office aspirants in Ondo State.

\begin{tabular}{|l|l|l|l|l|l|}
\hline S/No & $\begin{array}{l}\text { Political } \\
\text { Positions }\end{array}$ & $\begin{array}{l}\text { Number of } \\
\text { Candidates } \\
\text { Required }\end{array}$ & $\begin{array}{l}\text { Number of } \\
\text { contestants }\end{array}$ & $\begin{array}{l}\text { Total Number of } \\
\text { contestants }\end{array}$ & $\begin{array}{l}\text { Estimated Number } \\
\text { Number of posters }\end{array}$ \\
\hline 1 & Governor & 1 & 10 & 10 & $2,030,000$ \\
\hline 2 & Senator & 3 & 10 & 30 & $6,090,000$ \\
\hline 3 & Member House of Representative & 9 & 10 & 90 & $18,270,000$ \\
\hline 4 & Member House of Assembly & 26 & 10 & 260 & $52,780,000$ \\
\hline 5 & LGA Chairman & 18 & 10 & 180 & $36,540,000$ \\
\hline 6 & LGA Councillor & 203 & 5 & 1015 & $206,046,000$ \\
\hline \multicolumn{5}{|l|}{ TOTAL } \\
\hline
\end{tabular}

Source: Field work, 2012

In Table 2, it was assumed that 10 Governorship aspirants will supply 1000 posters each to each of the 203 wards $(10 * 1000 * 203=2,030,000) ; 30$ Members of House of Senate (MHS) aspirants will also supply 1000 posters to each of the 203 wards $(30 * 1000 * 203=6,090,000)$ : 90 Members of House Representative (MHR) aspirants will also supply 1000 posters to each of the 203 wards $(90 * 1000 * 203=18,270,000): 260$ Members of House Assembly (MHA) aspirants will also supply 1000 posters to each of the 203 wards $(260 * 1000 * 203=52,780,000)$ : 180 Local Government Area (LGA) Chairmen aspirants will supply 1000 posters to each of the 203 wards $(180 * 1000 * 203=36,540,000)$ : 1015 LGA Councillorship aspirants will also supply 1000 posters to each of the 203 wards $(1015 * 1000 * 203=206,045,000)$. In all, the estimated waste to be generated by political office seekers amount to $\mathbf{3 2 1 , 7 5 5 , 0 0 0}$ posters. The irony of it all is that no provision is always made for the removal of the posters. The implication is that the waste generated by this exercise is always enormous during and after the campaign periods.

\section{Posters and Banners generation and their Spatial Location in Urban Environment}

The city centre is most noted for the display of posters in Nigeria cities. It is believed that the Central Business District (CBD) is the most accessible part of any city, thus, the display of posters are usually concentrated in this region. The study revealed that $39 \%$ of the posters are usually found in this region (see Figure 2). Next to this, is the road network junction in cities which has about $22 \%$. Others are school/educational vicinities (15\%) church (8\%) and bus stops (16\%).

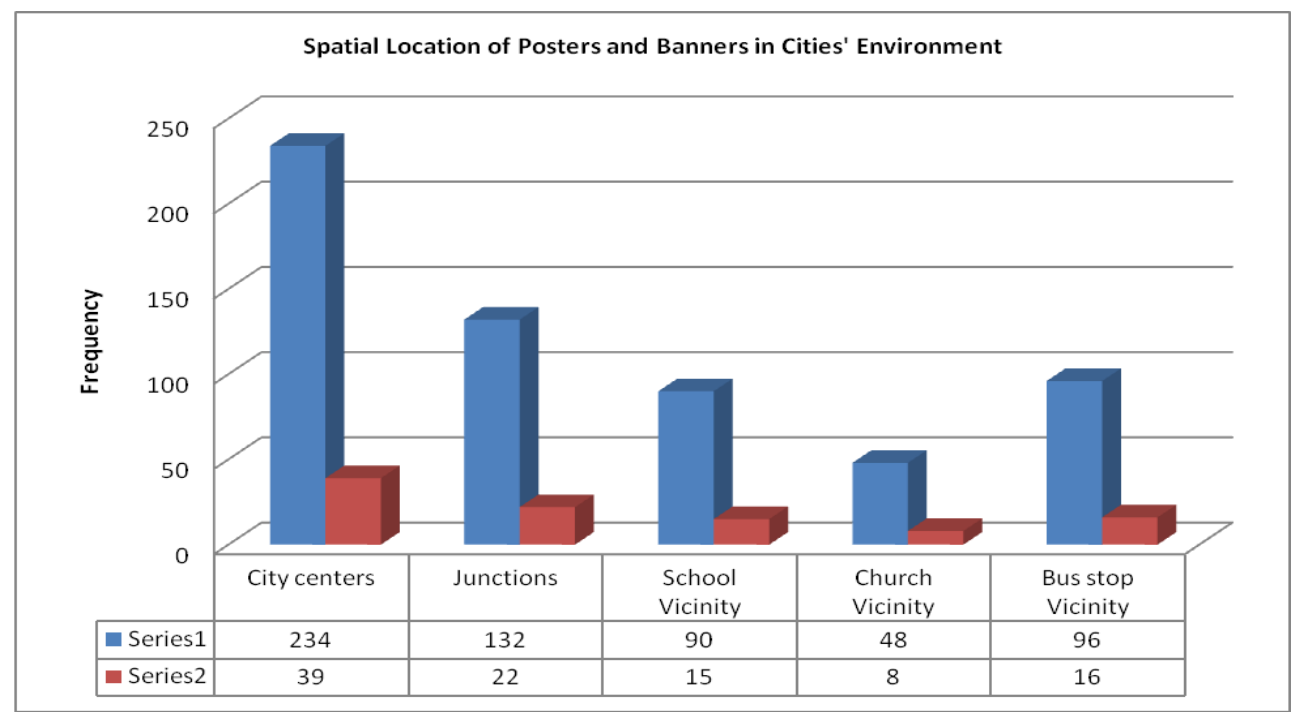

Figure 2: Spatial Location of Posters, Banners and Billboards in Cities Environment 


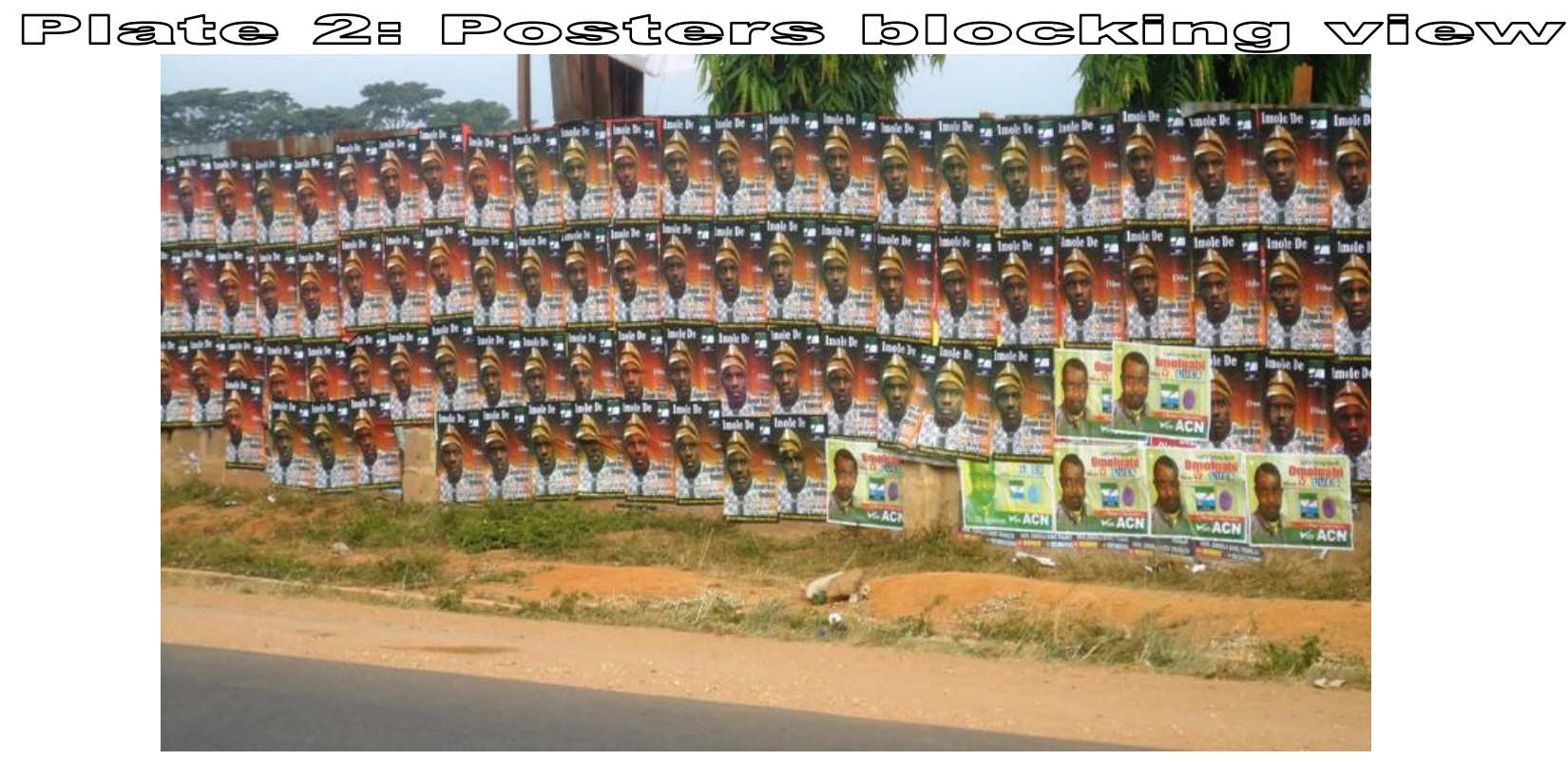

\section{Effects of posters and banners on Urban Environment}

Posters and banners are supposed to be used to inform and provide guides for people. However, when they are indiscriminately used and the volumes become too unwieldy, they become a nuisance rather than a means of information (see Plate 2). The situation of pasting posters and banners in Nigeria urban environment has risen to such a level that they block views and when close to road junctions could lead to accidents. In Lagos State, the Government has prohibited the display of these posters and banner. As a matter of fact, the government agents go about the nooks and crannies with a water tanker and sprayer to remove some of these posters. This exercise has been condemned in some quarters because people believed that it was only the opponents' posters that were being removed by the Government of the day.

A number of effects have been highlighted by this research and the respondents were made to give their own opinion using 4-point Likert perception scale of strongly agreed (SA), Agreed (A), Disagreed (D) and strongly disagreed (SD). Table 3 shows the way respondent perceived the pasting of posters and banners in urban environment.

$77.83 \%$ of the respondents perceived that indiscriminate display of posters and banners in urban environment as impairing one's ability to enjoy a view. According to these respondents, the aesthetic beauty that should ordinarily be enjoyed in the city's centres are marred by these posters. Other agreed effects from respondents include making environment untidy as well as disfiguring public structures which recorded $73.83 \%$ and $75.33 \%$ respectively.

Table 3: Effects of Posters, Banners and Billboards Distribution/Pasting on the Environment

\begin{tabular}{|l|l|l|l|l|l|l|l|l|l|}
\hline S/No & Effects & SA & A & D & SD & \multicolumn{4}{|c|}{ Percentages } \\
\cline { 7 - 10 } & & & & & Freq. & $\%$ & Freq. & $\%$ \\
\hline 1 & Reduces visibility & 125 & 137 & 198 & 140 & 262 & 43.67 & 338 & 56.33 \\
\hline 2 & $\begin{array}{l}\text { Un-removed posters and } \\
\text { billboards increase waste } \\
\text { generation n cities }\end{array}$ & 401 & 85 & 101 & 13 & 486 & 81.0 & 114 & 19.0 \\
\hline 3 & Make environment untidy & 204 & 239 & 120 & 37 & 443 & 73.83 & 157 & 26.17 \\
\hline 4 & Disfigures public structure & 265 & 187 & 101 & 47 & 452 & 75.33 & 148 & 24.67 \\
\hline 5 & $\begin{array}{l}\text { Impairing one's ability to } \\
\text { enjoy a view }\end{array}$ & 271 & 196 & 49 & 84 & 467 & 77.83 & 133 & 22.17 \\
\hline 6 & $\begin{array}{l}\text { Potent source of respiratory } \\
\text { diseases }\end{array}$ & 271 & 196 & 49 & 84 & 467 & 77.83 & 133 & 22.17 \\
\hline
\end{tabular}


Increase in waste generation with the uncontrolled way by which posters and banners are displayed in cities ranked the second as $81 \%$ of the respondent agreed with this statement while only $19 \%$ did not agreed, further inquiry shows that people just paste posters and banners in cities without making provision for their evacuation or removal after such programme must have been conducted. It does become the responsibility of the municipal Government to remove and collect such waste.

However, the fact that the display of posters and banners often reduces visibility in urban environment was not seen as a serious problem. The study shows that $56.33 \%$ of the respondent did not agreed that it reduces visibility while $43.67 \%$ agreed.

People $(77.83 \%)$ also believed that un-removed banners and posters could harbor micro-organisms that could cause respiratory diseases if left un-removed for a long time $\mathrm{e}^{10-14}$. From the foregoing, it is seen that posters and banners should be cautiously used in our environment.

\section{Remedies to challenges identified}

In view of the usefulness of posters and banners to politicians, educationists, religious bodies, entertainment industries, companies etc, outright stoppage is not advisable. There is need to educate those using posters and banners to publicise their intention to their audience to make provision for immediate removal of these materials as soon as their assignments are completed.

Orientation of people should also change by educating them to embrace audio and visual modes of publicizing their intention and pay less emphasis on the use of posters and banners. This study revealed that the intention for which posters and banners are intended are not often realized as people passed such posters without bordering on what message is being passed. Thus, radio and television which are veritable alternate means of passing information should be encouraged.

Apart from this, the world all over, encourage paperless activities as a major way of reducing solid waste in cities. This new trend should be embraced in the third world countries.

Government is therefore advised to enact a law to punish people who paste posters in unlawful places as revealed by ${ }^{7}$ Ojo (2010). This view further reinforce the fact that urban environment should be rid of indiscriminate pasting of posters, erection of masts, billboards and banners on public structures.

Finally, the Government should also work out a modality whereby taxes are imposed on posters, banners and billboards found in our environment.

\section{Conclusion}

Individuals determine differently what is attractive about their environment, based upon their aesthetic senses, expectations and experiences. It should therefore be noted however that the visual environment is integral to our daily experience of the built and natural environment and so must be kept clean as much as possible. The deplorable visual pollution situation in Nigeria urban environment has further impacted tension on refuse management principles. It has become a problem that bothers the entire citizenry because it can engineer the destruction of the quality of life in both urban and rural environment.

The major players in terms of mounting posters, banners and billboards as identified by this study should be monitored so that visual pollutions emanating from their ends could be curtailed as much as possible. It is only by doing this that the refuse generated through this process can be reduced.

Efforts should be made by Government to establish industries that can recycle paper waste emanating from posters to usable forms thereby turning waste to wealth.

\section{References}

[1]. American Lung Association (2012) America's most polluted cities are getting cleaner. http://www.citymayors/google

[2]. Osuntokun, A (1998) "Introduction" in Osuntokun, A and Davids, A (eds) Current Issues in Nigeria Environment, Nigeria, Ibadan press pp 4-6

[3]. Onwioduokit, E. A (1998) An Alternative Approach to Efficient Pollution Control in Nigeria in Osuntokun, A. and Davids, A (eds) Current Issues in Nigerian Environment, Nigeria, Ibadan press pp 36-48

[4]. Dun Foundation (2012) Visual Pollution. www.dunnfoundation.org/vp/index.html Copyright 1999-2012 downloaded on $2 / 3 / 2012$

[5]. Martindale, J. (2010) Graffiti Removal - Anti Graffiti Tips and Techniques. http://education.ezinemark.com/a/visual-pollutiongraffiti/\#ixzz1FzfyDBHV

[6]. WcP. Observer (2008) "Clean City" Sao Paulo says no to visual pollution, bans public advertising for a cleaner, more serene environment. $\quad$ www.worldculturepictorial.com/blog/content/clean-city-sao-paulo-says-no-visual-pollution-bans-publicadvertising-cleaner-more-serene-environment. down loaded on 3/4/2012

[7]. Ojo, D (2011) Advert Agency for Ondo State. The Nation Newspaper. Friday July, 2011. Nigeria. Pp 8.

[8]. Oketola, D (2011) Posters and Handbills Distribution as Lucrative Venture. The Punch Newspaper. Thursday, April 2011. Nigeria. pp 64

[9]. Olawepo, R. A. (2000) Environmental Pollution and Management Techniques in Jimoh, H. I. and I. P. Ifabiyi (eds) contemporary issues in Environmental Studies,Nigeria, Ilorin. Haytee publishing co., $1^{\text {st }}$ Edition.

[10]. Steve Last (2010) What is the definition of Visual Pollution? Can you give a good Example? Answerbag. http://www.answerbag.com/q. 
[11]. Amato, G., Liccardi, G., D’Amato, G and Holgate, S (2005) Environmental Risk Factors and Allergic Brochial Asthma. Clinical and Experimental Allergy. 35: 1113-1124.

[12]. Ring, j., Kramer, U., Schafer, T and Behrendt, H (2001) Why are allergies increasing? Current Opinion in Immunology. 13: 701-708.

[13]. D’Amato, G (2002) Environmental Urban Factors (air pollution and allergies) and the rising trends in allergic respiratory diseases. Allergy. 57: 30-33.

\section{Appreciation}

The authors wish to acknowledge the Management of Adekunle Ajasin University for providing the enabling environment to carry out this study as well as sponsoring the presentation of the paper at the $5^{\text {th }}$ International Conference of the Environment held at University of Terengganu, Terengganu, Malaysia between Nov. $22^{\text {nd }}$ and $24^{\text {th }}, 2012$. 